\title{
JORGE LOBO'S DISEASE: EXPERIMENTAL INOCULATION IN SWISS MICE
}

\author{
Diltor Vladimir Araújo OPROMOLLA(1), Suzana MADEIRA(2), Andréa de Faria Fernandes BELONE(3) \& Fátima Regina VILANI-MORENO(4)
}

\begin{abstract}
SUMMARY
Sixty-four isogenic Swiss mice were intradermically inoculated in both hind foot pads. The inocula, consisting of fungal suspensions from biopsies obtained from Jorge Lobo's Disease patients, had the total number of fungi and the viability index determined using a Neubauer chamber and the fluorescein diacetate-ethidium bromide technique (FD-EB), respectively. The animals were sacrificed at times ranging from ten days to eighteen months after inoculation. The cellular infiltrate, mainly consisting of macrophages containing fungi, increased progressively up to end of the study; however, no macroscopic alterations were observed in the inoculated feet. After nine months, small numbers of Langhans' giant cells started to appear in the infiltrate. A considerable number of fungi was observed at the end of the experimental period, but only a few were viable when stained by the FD-EB technique. This fact suggests that there is a multiplication of fungal cells, which are destroyed by the macrophages but remain in the tissue for a long time due perhaps to the difficulties in their elimination. These findings led us to conclude that in spite of the maintenance of the infection in these animals, Swiss mice cannot be considered an ideal model to study Jorge Lobo's Disease. However, the authors call attention to the possibility of other mouse strains being more susceptible to Paracoccidioides loboi.
\end{abstract}

KEYWORDS: Jorge Lobo's Disease; Swiss mice; Paracoccidioides.

\section{INTRODUCTION}

Keloid blastomycosis or Jorge Lobo's Disease was first described in 1931 by professor Jorge Lobo, in Recife?

Until now, its etiological agent, Paracoccidioides loboi (P. loboi) as designated by ALMEIDA \& LACAZ $^{1}$ in 1949, has not been cultivated in the laboratory. Although some investigators report success in this undertaking, the fungi obtained in culture do not correspond to the etiological agent of this disease ${ }^{7}$. Other issues concerning this mycosis, are still unknown, among them lack of knowledge about its pathogenesis and inexistence of an effective therapy.

The finding of an animal capable of experimentally reproducing this disease would bring good progress. With this purpose, inoculations were made in several animal species. When studying the first case of this disease, Jorge Lobo attempted to experimentally reproduce it in guineapigs, rats and Rhesus monkeys (Macaca mulata), inoculating them with ground skin containing parasites removed from one patient; however, he did not succeed ${ }^{10}$. Other unsuccessful attempts were made using guinea-pigs ${ }^{2,6,16}$, rats $^{2}$, mice ${ }^{2}$ and hamsters ${ }^{2}$ inoculated by the intratesticular, intraperitoneal, subcutaneous and intradermal routes. Similar results were obtained by CAMPO-AASEN ${ }^{5}$ when he inoculated material from cutaneous lesions in 34 mice by the intraperitoneal and cutaneous routes; nine animals were irradiated or treated with prednisone. This investigator later inoculated 14 rats by the peritoneal, testicular, nasal and caudal routes, but the results were also negative.

Subsequent studies were somewhat more encouraging. WIERSEMA $\&$ NIEMEL ${ }^{18}$ performed exhaustive inoculations in guinea-pigs, mice and hamsters by the intratesticular, intraperitoneal and subcutaneous routes; granuloma formation was observed in mouse foot pads however, there were no budding parasites; two hamsters showed granulomas identical to human granulomas in the foot pads, with budding parasites. Similarly, AZULAY et al. ${ }^{3}$ inoculated two mice intradermally (foot pad) and 14 rats intratesticularly; in the inner portion of one rat testis, granulomas with budding fungi were observed 7-8 months after inoculation, and microscopic alterations similar to those described for the disease in human beings were observed in one intradermally inoculated mouse, after 13 months and 24 days.

SAMPAIO \& DIAS ${ }^{12}$ inoculated 22 hamsters (Mesocricetus auratus) cheek pouches and obtained nodular lesions consisting of histiocytes and giant cells containing parasites. Similar results were found in chelonians from the Amazon region (Geochelone denticulata, Geochelone carbonaria and Kinosternon scorpioides) and in armadillos (Euphractus sexcinctus) by SAMPAIO et al. ${ }^{13}$ and SAMPAIO \& DIAS ${ }^{14}$, respectively.

(1) Divisão de Pesquisa e Ensino, "Instituto Lauro de Souza Lima", Bauru, SP, Brasil.

(2) Equipe Técnica de Microbiologia, "Instituto Lauro de Souza Lima", Bauru, SP, Brasil.

(3) Equipe Técnica de Patologia, "Instituto Lauro de Souza Lima", Bauru, SP, Brasil.

(4) Equipe Técnica de Imunologia, "Instituto Lauro de Souza Lima", Bauru, SP, Brasil.

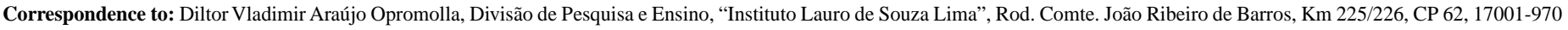
Bauru, SP, Brasil. Fax: 014-2304747, Tel.: 014-2302244. E-mail: pesquisa@ilsl.br 
The results of the experimental inoculations are still not entirely satisfactory. Only a few authors have achieved positive but inconsistent results, and they used a small number of animals; they did not use viability criteria and they did not mention the number of inoculated fungi. Therefore, further studies are needed for a better understanding of the parasite-host interaction mechanisms in this mycosis, and to determine the most adequate animal model. Considering the fact that mice are the species most frequently utilized in the experimental studies of paracoccidioidomycosis whose etiological agent, at least up to this moment, belongs to the same genus as the Jorge Lobo's Disease causative agent, we inoculated $P$. loboi in these rodents, taking into account the inoculation site, the size of the inoculum and its viability.

\section{MATERIAL AND METHODS}

Mouse foot pads were inoculated with known fungal concentrations and viability indices of suspensions obtained from biopsies of keloid lesions from Jorge Lobo's disease patients, as follows:

1. Biopsies -11 biopsies from 8 patients from the State of Acre were collected, listed as cases, and numbered 1 to 8 . Each skin fragment was immediately macerated in Hank's saline and $0.85 \%$ saline.

2. Viability and fungal concentration - fungal viability in the suspension was determined using vital staining with fluorescein diacetate-ethidium bromide (FD-EB) ${ }^{4}$ standardized for $P$. loboi by VILANI-MORENO \& OPROMOLLA ${ }^{17}$. The fungal cell concentration was estimated with a Neubauer chamber and the results are expressed as absolute numbers (Table 1).

3. Inoculation - both hind foot pads of 64 Swiss isogenic male and female mice from the "Instituto Lauro de Souza Lima" animal facilities, Bauru (SP), were intradermally inoculated. The animals received $0.03 \mathrm{ml} /$ foot of a fungal suspension and were mantained at temperatures of 22 to $25^{\circ} \mathrm{C}$.

4. Sacrifice - the animals were randomly sacrificed at 10 days and once a month up to eighteen months after inoculation.

5. Foot pad excision - the foot pads were excised, the right pads were submitted to histopathological examinations, and the left pads were macerated in $1 \mathrm{ml} 0.85 \%$ saline to count the fungi and determine viability. The histological sections were stained with hematoxylineosin (HE) and methenamine-silver ${ }^{8}$.

Table 1

Concentration of fungi/ml and viability of the biopsies used for inoculation

\begin{tabular}{lll}
\hline Case number (patient) & Fungal concentration/ml & Viability (\%) \\
\hline 01 (N.F.S.) & $1.0 \times 10^{6}$ & 27 \\
02 (M.C.M.) & $6.0 \times 10^{5} ; 4.2 \times 10^{5}$ & $48 ; 40$ \\
03 (M.B.) & $2.0 \times 10^{6}$ & 12 \\
04 (M.C.S.) & $7.0 \times 10^{5}$ & 11 \\
05 (A.M.O.) & $1.8 \times 10^{6} ; 1.4 \times 10^{6}$ & $45 ; 48$ \\
06 (R.C.P.) & $1.5 \times 10^{6}$ & 43 \\
07 (E.A.S.) & $1.7 \times 10^{6}$ & 20 \\
08 (S.P.S.) & $2.6 \times 10^{6} ; 2.8 \times 10^{6}$ & $39 ; 29$ \\
\hline
\end{tabular}

\section{RESULTS}

Since the histopathological alterations observed in the inoculated animals had similar characteristics at specific periods of time, these animals were grouped as follows: Group I - sacrificed within 10 days and 5 months; Group II - within 6 and 9 months; Group III - within 10 and 15 months; and Group IV - within 16 and 18 months.

In Group I, somewhat differentiated macrophages were first observed next to a great number of polymorphonuclear neutrophils (PMNs) and a few fungi. Approximately one month after inoculation the PMNs disappeared and a granuloma predominantly made up of macrophages with a small number of fungi was observed (Figure 1). Next to these macrophages, there were others only identified by densely HE stained nuclei, in arcuate form, seemingly surrounding the fungus in the cytoplasm that could not be well individualized. The cells where fungi were present exhibited one or two nuclei in apparent contact with the fungi, showing that they were phagocytized by these histiocytes. At that time, in silver-stained material, a certain amount of argentophilic granular material was observed deposited on the tissue, probably representing fungal cells debris (Figure 2). After the $5^{\text {th }}$ month, the granuloma was of a moderate size and made up of macrophages, a small number of lymphocytes, occasional mast cells and fibrocytes, and a larger number of fungi. In Group II, the granuloma continued to be moderate and was made up of macrophages, a small number of lymphocytes, scarce mast cells, fibrocytes, and Langhans'giant cells which appeared for the first time. In general, the fungi were observed in small quantities, not well stained by methenamine-silver, and a larger amount of argentophilic granular material was present. Group III presented a moderate granuloma composed almost exclusively of macrophages, scarce foreign body giant cells, a small number of lymphocytes, few fungi and argentophilic material. At the end of the experiment (Group IV), the granulomas became progressively larger and made up of macrophages, foreign type and Langhans' giant cells, few lymphocytes, some mast cells and fibrocytes, many fungi and a moderate quantity of granular argentophilic material (Figures 3 and 4). Macroscopic lesions characterized by increased foot volume were not observed.

The groups of animals sacrificed at different times, the concentration of inoculated fungi and their respective viability are shown in Table 2.

Table 3 shows the number of fungi/ml recovered in the excised foot pads at the different times and their respective viabilities.

\section{DISCUSSION}

Many authors have attempted to reproduce Jorge Lobo's Disease in several animals using different inoculation routes. Nevertheless, none of them, including those that claimed to have obtained positive results, mentioned the amount or the viability index of the inoculated fungi utilized in their experiments.

Counting the fungi is important not only to have an idea about the number of parasitic cells which are inoculated, but also to estimate a possible microorganism multiplication. The importance of the viability index is even greater because it determines how many living fungi capable of multiplying are being inoculated. The ideal then would be to use larger inocula containing a higher percentage of viable fungi. 


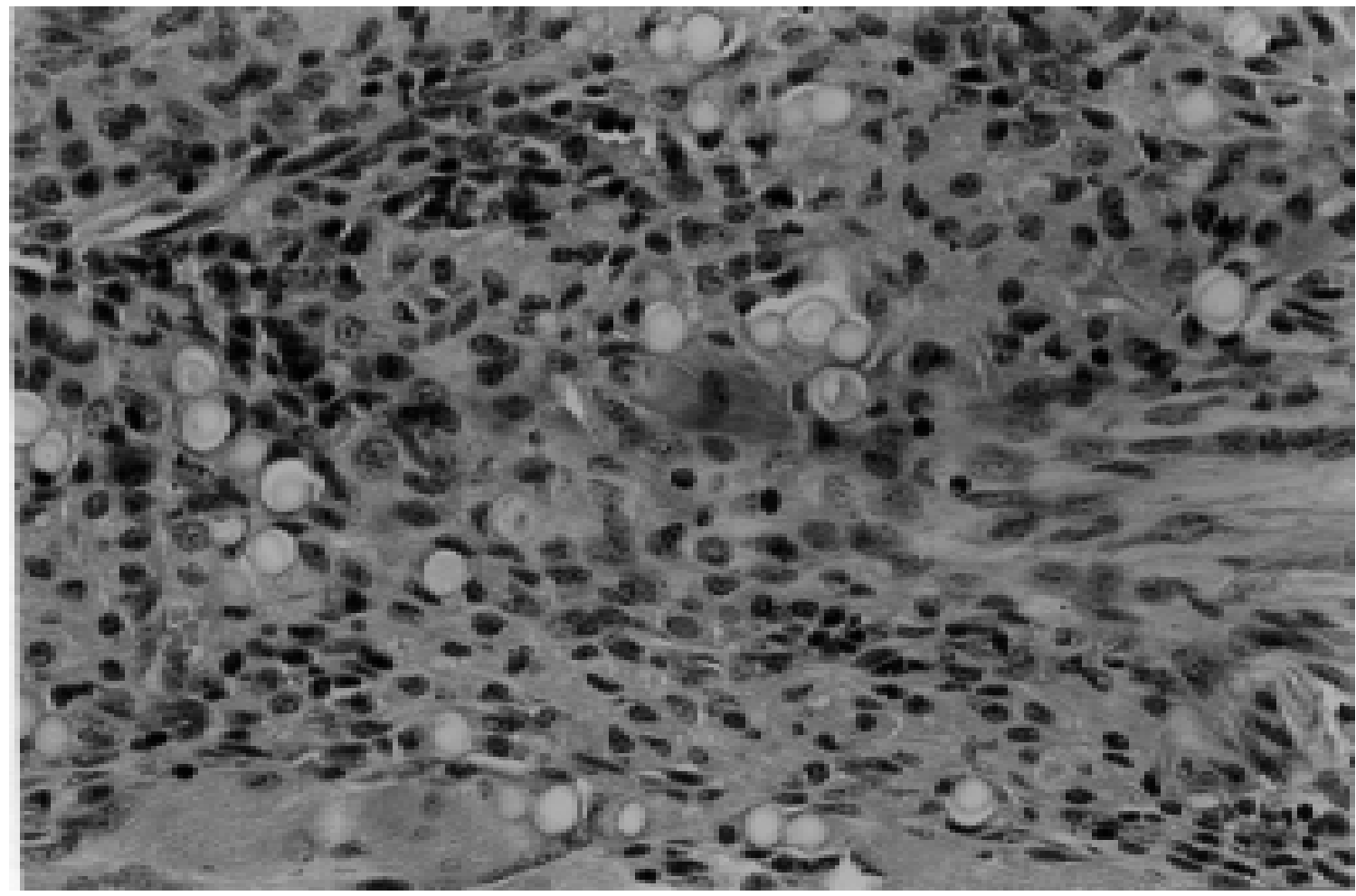

Fig. 1 - Histologic picture of a mouse foot pad 30 days after inoculation. Numerous macrophages containing fungi are observed (HE; 400x).

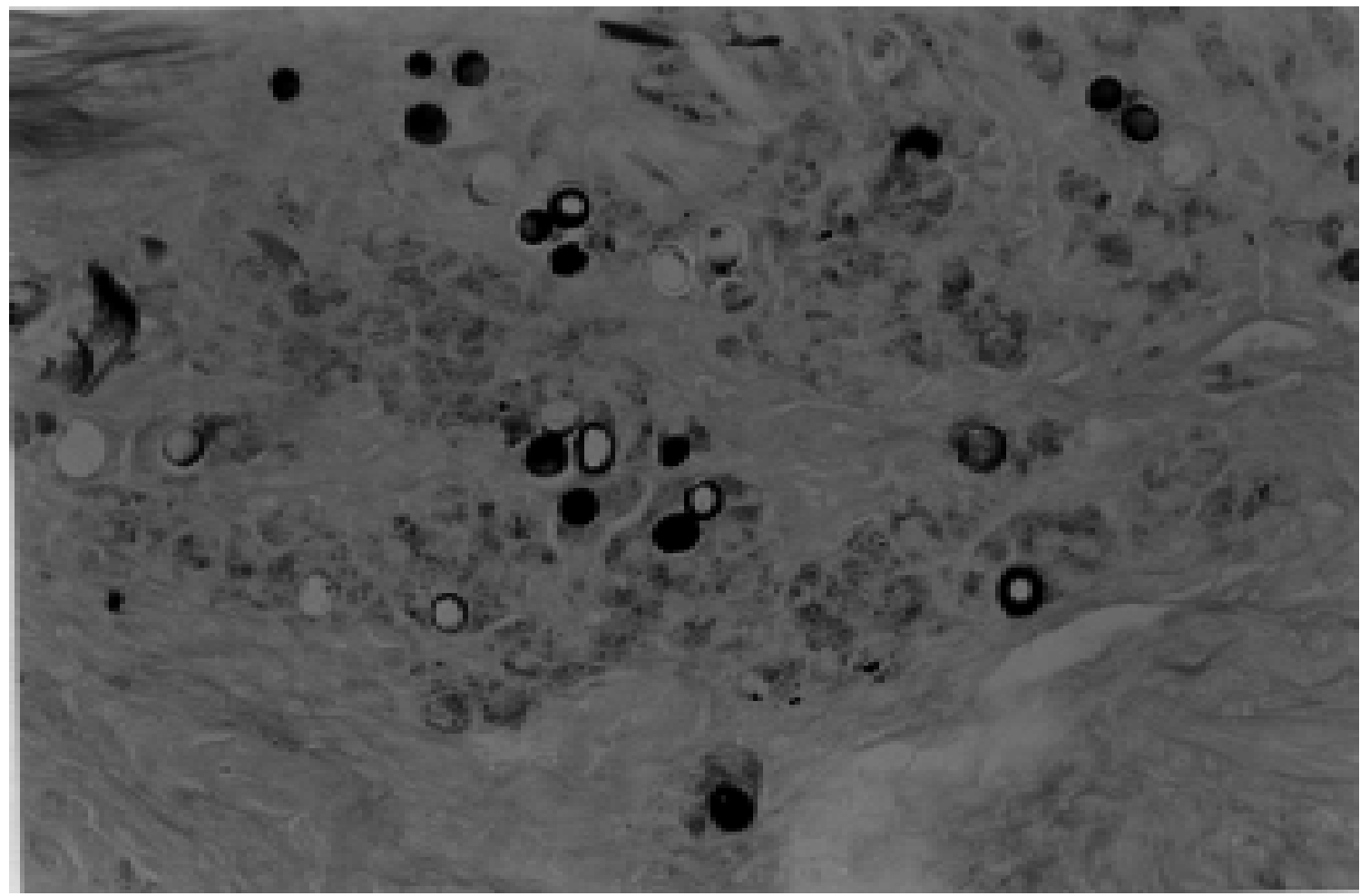

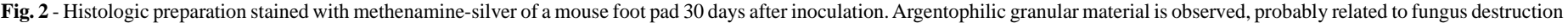
$(400 x)$. 


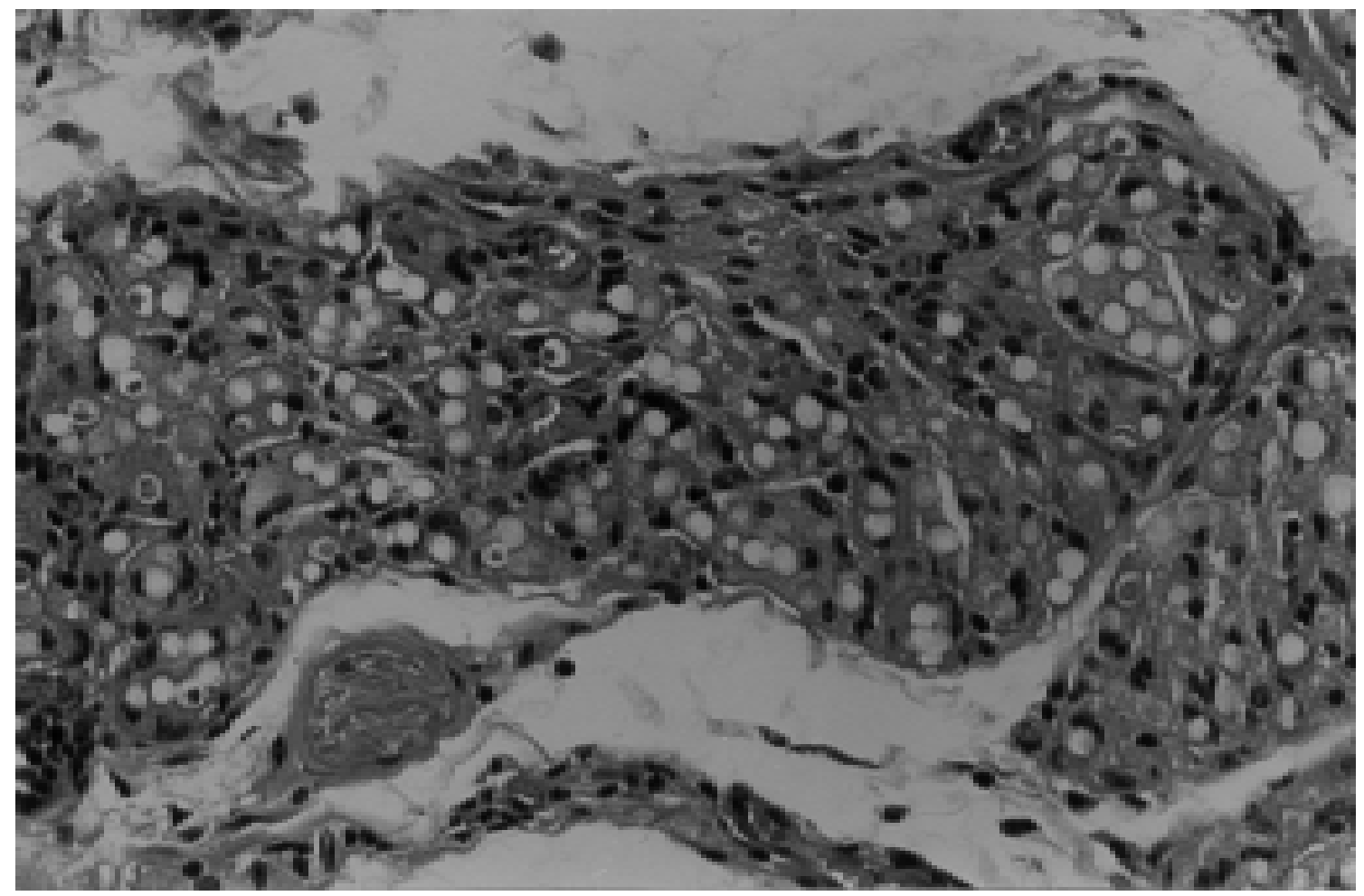

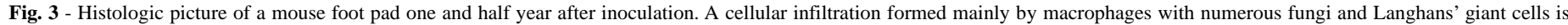
observed (HE; 400x).

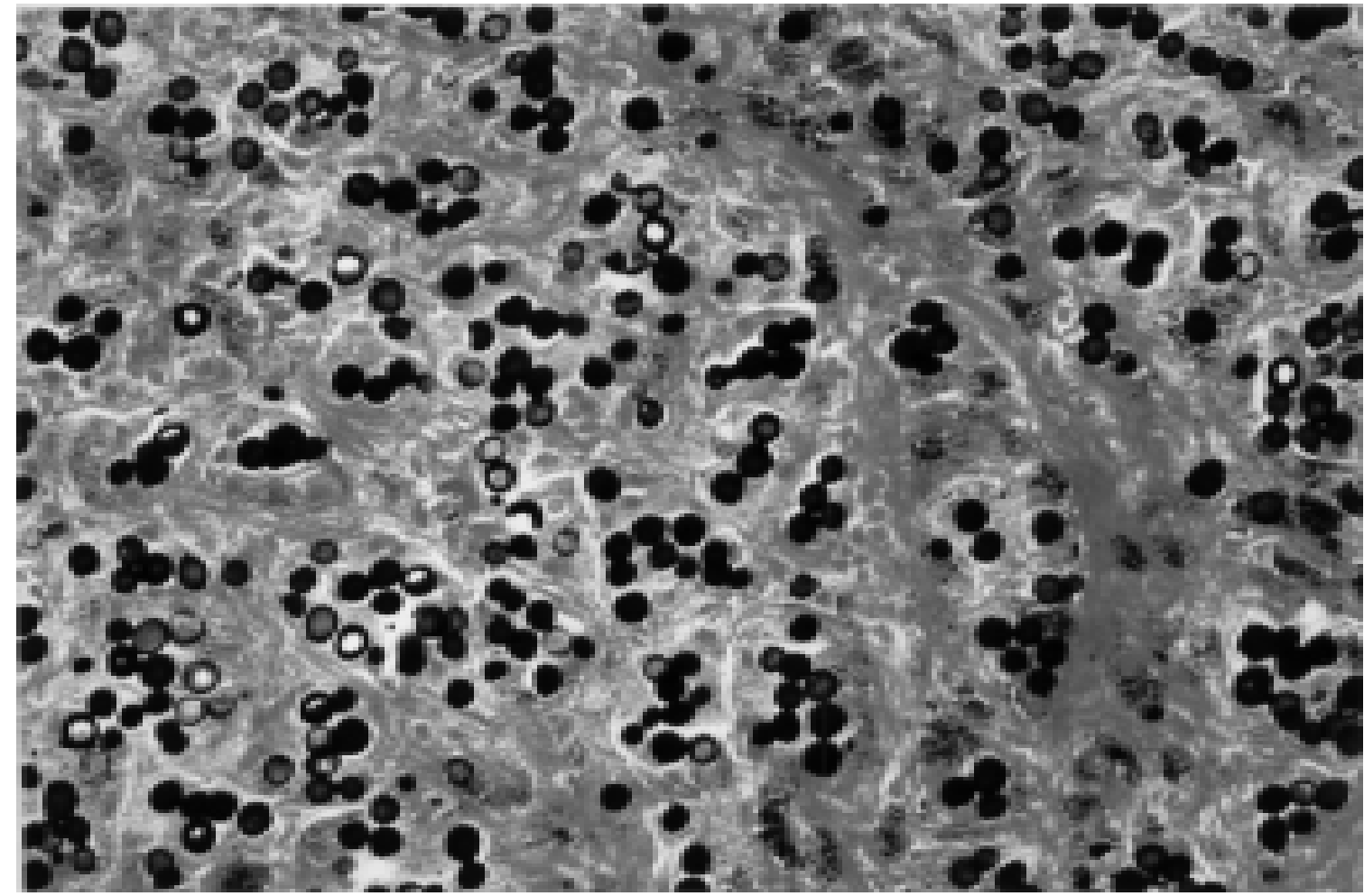

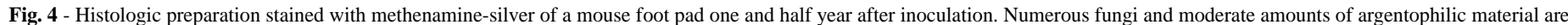
observed (400x). 
Table 2

Initial concentration of fungi/ml and viability per group of animals

\begin{tabular}{ccc}
\hline Group & Concentration (fungi/ml) & Viability $(\%)$ \\
\hline I & $4.2 \times 10^{5}$ to $1.4 \times 10^{6}$ & 27 to 48 \\
II & $7.0 \times 10^{5}$ to $2.0 \times 10^{6}$ & 11 to 43 \\
III & $6.0 \times 10^{5}$ to $1.7 \times 10^{6}$ & 20 to 48 \\
IV & $4.2 \times 10^{5}$ to $2.8 \times 10^{6}$ & 20 to 48 \\
\hline
\end{tabular}

Table 3

Concentration of fungi/ml and recovered viability per group of animals according to time of sacrifice

\begin{tabular}{ccc}
\hline Group & Concentration (fungi/ml) & Viability \\
\hline I & $1.25 \times 10^{4}$ to $7.25 \times 10^{4}$ & Not done \\
II & $5.0 \times 10^{3}$ to $6.0 \times 10^{4}$ & Not done \\
III & $1.9 \times 10^{4}$ to $1.8 \times 10^{5}$ & Negative (08); positive (05) \\
IV & $1.0 \times 10^{4}$ to $8.0 \times 10^{5}$ & Negative (14); positive (09) \\
\hline
\end{tabular}

We tried to standardize an experimental murine model for the study of Jorge Lobo's Disease utilizing Swiss mice. The number of fungi inoculated was determined in a Neubauer chamber and the FD-EB stain was used to determine the viability index. However, the inocula were from different patients and contained different numbers of fungal cells and had different viability indices. The number of fungi was large and did not substantially differ among inocula as shown in Table 1 , but viability varied considerably with percentages ranging from $11 \%$ to $48 \%$. In spite of these differences all the mice examined showed a relatively uniform pattern of alterations depending on the period of sacrifice.

Granulomas were observed in all the inoculated foot pads, although none of them was sufficiently large to be clinically detected. Many macrophages in the infiltrates apparently did not contain fungi or exhibited only capsule fragments inside them. These cells may correspond to cells erroneously designated by some authors as xanthoma cells in skin biopsies from Jorge Lobo's Disease patients. These macrophages were studied by SESSO \& BARUZZI ${ }^{15}$, also using electron microscopy.

In the $9^{\text {th }}$ month after inoculation some Langhans' and foreign body giant cells appear; they increase in number at other times but they do not become as numerous as those observed in the human lesions of this mycosis. What calls attention is the always small number of lymphocytes, as observed in human lesions.

In the final months, there is a clear enlargement of the granulomas that, in addition to an increase in the number of macrophages, also show a higher number of giant cells. The fungi apparently grow in number and, albeit most of them present irregular staining by methenamine-silver, some are well stained and apparently viable ${ }^{11}$. The number of recovered fungi is lower than that used for the inoculum, but the viability index, although also smaller, is positive, showing that the process is active.
Considering the results, Swiss mice inoculated with P.loboi are not a good model to study Jorge Lobo's Disease, first of all because no macroscopic lesions were observed, and secondly because the number of viable fungi found at the end of the experiment was too small.

Histological findings were similar in some aspects to those observed in the human disease. The presence of viable fungi even 18 months after from inoculation and the large number of dead fungi in the tissue suggest that the fungi that are not destroyed by macrophages continue to multiply and those already dead are slowly eliminated from the body of the animal, which are unable to cope with them quickly. As a result, a large amount of fungi is observed in the tissue, most of them non-viable. The fungi digested by macrophages are responsible for the accumulation of argentophilic material inside them.

Nevertheless, just as there is a mouse strain more susceptible to infection by Paracoccidioides brasiliensis, i.e. is the B10.A strain, a better strain may also exist for P. loboi development. For this reason, the investigations must continue and we are already working with this objective.

\section{RESUMO}

\section{Doença de Jorge Lobo. Inoculação experimental em camundongos suiços}

Foram inoculados por via intradérmica, os coxins plantares traseiros de 64 camundongos Suíços, isogênicos. Os inóculos constituídos de uma suspensão fúngica, obtidos de biópsias de pacientes portadores de Doença de Jorge Lobo, foram submetidos a contagem do número total de fungos em câmara de Neubauer e a determinação da viabilidade segundo técnica do diacetato de fluoresceína-brometo de etídeo (DF-BE). Os animais foram sacrificados em períodos de tempo que variaram de 10 dias a 18 meses pós-inoculação. Um infiltrado celular constituído essencialmente por macrófagos com fungos no seu interior foi aumentando progressivamente até o final da experimentação, entretanto não houve alterações macroscópicas das patas inoculadas. Um pequeno número de células gigantes tipo Langhans começou a aparecer no infiltrado aos 9 meses. Um número considerável de fungos foi observado no período final do experimento, mas quando submetidos a coloração pelo DF-BE somente alguns deles estavam viáveis. Por esse motivo os autores sugerem que existe uma multiplicação de fungos, mas que são destruídos pelos macrófagos e permanecem no tecido um longo período de tempo talvez devido a dificuldade em sua eliminação. Estes achados levam a conclusão que apesar da manutenção da infecção nesses animais, os camundongos Suíços podem não ser considerados um modelo ideal para o estudo da Doença de Jorge Lobo. Entretanto, os autores chamam a atenção para a possibilidade de outras linhagens de camundongos serem mais susceptíveis ao $P$. loboi.

\section{REFERENCES}

1. ALMEIDA, F.P. \& LACAZ, C.S. - Blastomicose "tipo Jorge Lobo". An. Fac. Med. S. Paulo, 24: 5-37, 1948-1949.

2. AZULAY, R.D. \& MIRANDA, J. - Doença de Jorge Lobo ( $15^{\circ}$ caso da literatura). Hospital (Rio de J.), 51: 685-691, 1957. 

41(6): 359-364, 1999.

3. AZULAY, R.D.; ANDRADE, L.C.; SILVA, D. \& CARNEIRO, J. - Reprodução experimental da blastomicose de Jorge Lobo. An. bras. Derm., 43: 261-266, 1968.

4. CALICH, V.L.G.; PURCHIO, A. \& PAULA, C.R. - A new fluorescent viability test for fungi cells. Mycopathologia (Den Haag), 66: 175-177, 1978.

5. CAMPO-AASEN, I. - Blastomicosis queloidiana o enfermedad de Jorge Lobo en Venezuela. Derm. venez., 1: 215-240, 1958.

6. CERRUTI, H. \& ZAMITH, V.A. - Doença de Jorge Lobo. (Comunicação à Sociedade Paulista de Medicina em 1948).

7. FONSECA, O.J.M. \& LACAZ, C.S. - Estudo de culturas isoladas de blastomicose queloidiforme (doença de Jorge Lobo). Denominação de seu agente etiológico. Rev. Inst. Med. trop. S. Paulo, 13: 225-251, 1971.

8. GROCOTT, R.G. - A stain for fungi in tissue sections and smears using Gomori's methenamine-silver nitrate technic. Amer. J. clin. Path., 25: 975-979, 1955.

9. LACAZ, C.S.; PORTO, E. \& MARTINS, J.E.C. - Micologia médica: fungos, actinomicetos e algas de interesse médico. 8. ed. São Paulo, Sarvier, 1991.

10. LOBO, J. - Contribuição ao estudo das blastomicoses. An. Fac. Med. Recife, 39: 4-5, 1938.

11. OPROMOLLA, D.V.A.; VILANI-MORENO, F.R. \& BELONE, A.F.F. - A doença de Jorge Lobo e a coloração pela prata metenamina. An. bras. Derm., 1999 (in press).
12. SAMPAIO, M.M. \& DIAS, L.B. - Experimental infection of Jorge Lobo's disease in the cheek-pouch of the golden hamster (Mesocricetus auratus). Rev. Inst. Med. trop. S. Paulo, 12: 115-120, 1970.

13. SAMPAIO, M.M.; DIAS, L.B. \& SCAFF, L. - Bizarre forms of the aetiologic agent in experimental Jorge Lobo's disease in tortoises. Rev. Inst. Med. trop. S. Paulo, 13: 191-193, 1971

14. SAMPAIO, M.M. \& DIAS, L.B. - The armadillo Euphractus sexcinctus as a suitable animal for experimental studies of Jorge Lobo's disease. Rev. Inst. Med. trop. S. Paulo, 19: 215-220, 1977.

15. SESSO, A. \& BARUZZI, R.G. - Interaction between macrophage and parasite cells in lobomycosis. The thickened cell wall of Paracoccidioides loboi exhibits apertures to the extracellular milieu. J. submicrosc. Cytol. Path., 20: 537-548, 1988.

16. TREJOS, A. \& ROMERO, A. - Contribuição ao estudo das blastomicoses na Costa Rica. In: CONGRESSO INTERNACIONAL DE MICROBIOLOGIA, 5., Rio de Janeiro, 1950. Resumos. p.127.

17. VILANI-MORENO, F.R. \& OPROMOLLA, D.V.A. - Determinação da viabilidade do Paracoccidioides loboi em biópsias de pacientes portadores de doença de Jorge Lobo. An. bras. Derm., 72: 433-437, 1997.

18. WIERSEMA, J.P. \& NIEMEL, P.L. - Lobo's disease in Surinam patients. Trop. geogr Med., 17: 89-111, 1965.

Received: 11 May 1999

Accepted: 24 September 1999 